\title{
REVIFWS OF BOOKS
}

Introduction à l'Etude des Anciens Codes Orientaux. By J. Teroy

me de Feu. By C. M. Edsman (A. S. Tritton) •

Die Familie bei den heutigen Beduinen Arabiens und seiner Randgebiete. By j. Henninger

(A. S. Tritton)

La Métaphore dans le Coran. By T. Sabbagh (A. S. Tritton)

Cinco Poetas Musulmanes. By E. Garcia Gómez (A. S. Tritton)

Al-Ghazāli the Mystic. By Margaret Smith (A. S. Tritton)

Tkhwān uş-Saf ā. By 'Umar Farrūkh (A. S. Tritton)

Bashshār ibù Burd. By 'Umar Farrūkh (A. S. Tritton)

Hakim al-Ma'arra. By 'Umar Farrūkh (A. S. Tritton)

Ibn Bajja (Avempace) and the Philosophy in the Moslem West. By 'Umar Farrūkh (A. $\mathbf{S}^{\circ}$ Tritton)

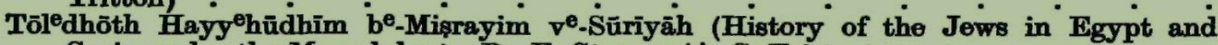
Syria under the Mamelukes). By E. Strauss (A. S. Tritton) .

Nahwa at-ta'āwun al-'arabi. By 'Umar Farrūkh (A. S. Tritton)

Mythes Astrals et Traditions littéraires. By H. Pernot (A. S. Tritton)

A Short History of Transjordan. By B. Toukan (A. S. Tritton)

Tableau des Racines Sémitiques. By Baron Carra de Vaux (A. S. Tritton)

Iexique Arabe-Français. By L. Bercher (A. S. Tritton)

L'Islam Maghrebin. By G. H. Bousquet (A. S. Tritton)

Recherches sur le Vocalisme, le Consonantisme, et la Formation des Racines en "Nostratique". By A. Cuny (A. S. Tritton)

Connaissance (A. S. Tritton)

Sogdica. By W. B. Henning (I. Gershevitch)

Caste in India. By J. H. Hutton (S. G. Vesey-FitzGerald)

History of Hindu Public Life. By U. N. Ghoshal (L. D. Barnett) .

Kautalya Studies. By Sten Konow (L. D. Barnett)

Highways and Byways of Literary Criticism in Sanskrit. By S. S. Kuppuswami Sastri (L. D. Barnett)

The Hill Tribes of Jeypore. By Lakshmi Narayana Sahu (L. D. Barnett)

Probleme der indischen Religionsgeschichte. By W. Koppers (L. D. Barnett) : $\quad$ :

Rājasthāna-bhāratī (L. D. Barnett)

Flementary Urdu. By H. Catchpole (J. V. S. Wilkinson)

Structure Grammaticale des Langues Dravidiennes. By J. Bloch (T. Burrow)

The Heritage of Karnātaka. By R. S. Mugali (A. Master) . Winstedt)

Richard Hakluyt and his Successors (Sir R. O. Winstedt)

A Burmese-Fnglish Dictionary. By J. A. Stewart and C. W. Dunn (L. D. Barnett)

Contes Populaires Inédits du Cambodge. By F. Martini and S. Bernard (J. A. Stowart) -

Newspaper Chinese by the Inductive Method [with Translation of Text, etc.]. By H. G. Creel and Têng Ssŭ-yü (W. Simon)

Readings in Traditional Chinese. Edited by Chi-chen Wang (A. D. Waley) : $\quad$ : $\quad$ :

Dictionary of Japanese Sōsho Writing Forms. By Otome Daniels (A. D. Waley) .

Japanese Prose. By F. J. Daniels (A. D. Waley)

Handbook of Japanese Gramamar. By H. Henderson (A. D. Waley) combe Gunn)

Gafat Documents. By Woif Leslau (A. S. Tritton)

Bantue-Filosofie. By P. P. Tempels (L. Stappers)

LIST OF BOOKS RECEIVED FOR REVIEW

OBITUARY NOTICE : GORDON MATTHEWS

\section{Editor : PROFESSOR R. L. TURNER, Director}

\section{All communications to be addressed to-}

\author{
THE EDTTOR OF THE BuLLETIN, \\ Sohool of Ortental and African Studies Library, \\ MaLeT Streft, \\ LoNDON, W.C. 1.
}

